\title{
What Did We Do to Our Mountain? African Eco-Feminist and Indigenous Responses to Cyclone Idai in Chimanimani and Chipinge Districts, Zimbabwe
}

\section{Sophia Chirongoma ${ }^{1}$ and Ezra Chitando ${ }^{2}$}

\section{SHORT BIO}

${ }^{1}$ Sophia Chirongoma is a Senior Lecturer in the Religious Studies Department at Midlands State University, Zimbabwe. She is also an Academic Associate/Research Fellow at the Research Institute for Theology and Religion (RITR) in the College of Human Sciences, University of South Africa (UNISA)

${ }^{2}$ Ezra Chitando is a Professor of History and Phenomenology of Religion at the University of Zimbabwe. He also serves as the World Council of Churches Ecumenical HIV and AIDS Initiatives and Advocacy Theology Consultant on HIV and AIDS.

\section{INSTITUTIONAL AFFILIATION}

${ }^{1}$ Religious Studies Department at Midlands State University, Zimbabwe; Research Institute for Theology and Religion (RITR) in the College of Human Sciences, University of South Africa (UNISA); sochirongoma@gmail.com or sochirongoma@yahoo.com

${ }^{2}$ History and Phenomenology of Religion at the University of Zimbabwe, World Council of Churches; chitsa21@yahoo.com

\section{ORCID}

${ }^{1}$ https://orcid.org/0000-0002-8655-7365 ${ }^{2}$ https://orcid.org/0000-0003-2493-8151

\section{ABSTRACT}

Cyclone Idai caused untold devastation in Chimanimani and Chipinge districts, Zimbabwe. In scenes reminiscent of the biblical deluge, in some places entire settlements were eradicated from the face of the earth. Houses were swept away, bodies were submerged and water, typically understood as the source of life, became the source of death. Individuals, families, communities and nations were left traumatized, and the search for meaning continues. Inevitably, religion featured prominently in explanations of this tragedy. This article is a preliminary review of the explanations of Cyclone Idai in Chimanimani and Chipinge districts, Zimbabwe, within the frame of African Traditional Religion/s (ATR/s) and Christianity. The article delves into questions at the interface of climate change and religion, such as: how do survivors of the cyclone explain its occurrence? What do we learn about the interface between religion and climate change in Africa from the responses to Cyclone Idai in Chimanimani and Chipinge districts? The article adopts the African ecofeminist perspective. This is informed by the fact that women and girls comprise the bulk of the population heavily impacted by Cyclone Idai in Chimanimani and Chipinge as well as the fact that they are the ones who were in the forefront of mitigating the impact of devastation caused by this ecological catastrophe. Our article seeks to contribute to the ongoing scholarly discussions on the nexus between religion, gender and climate change by foregrounding the experiences of women and girls affected by Cyclone Idai. The first part of the article describes the devastation caused by Cyclone Idai. The second part outlines the Christian and indigenous interpretations of the cyclone. The third part of the article teases out the indigenous interpretations of unpredictable weather patterns.

\section{KEYWORDS}

African Ecofeminism, Zimbabwe, climate change, Cyclone Idai, ecological crisis, religion 


\section{Introduction}

On March 15, 2019, Cyclone Idai slammed into the Chimanimani Mountains that form the border between Zimbabwe and Mozambique. Torrential rain and sustained winds up to $190 \mathrm{~km}$ per hour flattened this low-lying area. It set off landslides that have altered the landscape in the Zimbabwe highlands. The most severe devastation occurred in Chimanimani and Chipinge districts, as Chimanimani district was literally in the eye of the storm. Officials in Zimbabwe estimate that 171 people died, 326 went missing, 4073 people were displaced, and 2251 houses were destroyed. Utilizing the African eco-feminist lenses and drawing insights from the field research conducted in Chimanimani district, this article seeks to reflect on the indigenous and Christian explanations offered by the survivors of Cyclone Idai as they grapple to articulate their understanding of what actually triggered this enervating tragedy.

As academic-activist researchers interested in exploring the interface between religion and climate change with a focus on human rights advocacy and gender justice, the following key questions undergird this multidisciplinary study: (1) What are the Christian and indigenous explanations articulated by the survivors of Cyclone Idai in Chimanimani and Chipinge districts to make sense of this death-dealing and life-changing disaster? (2) In light of the indigenous and Christian responses to Cyclone Idai in Chimanimani and Chipinge districts, what lessons can be derived from the nexus between religion and climate change in Africa? (3) How do the debilitating effects of Cyclone Idai, as experienced in Chimanimani and Chipinge districts, contribute to the ongoing discussion surrounding the interconnection between religion, climate change, gender justice, and risk and disaster management initiatives in Zimbabwe?

\section{Scope of study and research design}

Chimanimani and Chipinge districts are located in Manicaland province in the eastern part of Zimbabwe. The study chose to focus on these two districts as they were the most affected. According to the most recent official census conducted in Zimbabwe in 2012, Chimanimani district had a total 
population of 134,940 and Chipinge Urban, where the study was conducted, had a total population of $25,292 .^{1}$ The study participants were purposively sampled from five temporary shelters where displaced survivors were residing. The required permissions from the study participants and relevant district officials in both Chimanimani and Chipinge districts were acquired. The approximate population of residents at these five temporary shelters was 1500. Data was collected through conducting in-depth interviews with ten survivors of Cyclone Idai from each of the five temporary shelters, making a total of 50 interviews. This article is a summary of the key issues emerging from the interviews. Since there were more women than men residing in these temporary sites, the distribution of study participants was tilted towards women-with 40 women and 10 men. Study participants fell between the ages of 18 and 65, thus affording an intergenerational perspective. The field research was conducted in April 2019, barely a month after the catastrophe had occurred.

\section{African ecofeminism theoretical framework}

The main thrust of eco-feminism is to engage in ecological conservation for the benefit of future generations tapping into female activism. ${ }^{2}$ The ecofeminist premise is based on the belief that there is an intertwined relationship between women and nature. ${ }^{3}$ Hence, the harm or degradation suffered by nature impacts women more heavily due to their closer interconnection. ${ }^{4}$ As noted by Jamie Thompson, ${ }^{5}$ "Ecofeminism seeks to emphasize the interconnectedness of all creation through caring for the

1 Zimbabwe Population Census 2012: Provincial report, Manicaland. (Zimbabwe: ZimStat, Zimbabwe National Statistics Agency, 2013) 22.

2 Isabel Apawo Phiri, "The Chisusmphi Cult: The Role of Women in Preserving the Environment" in Ruether R.R. ed., Women Healing Earth: Third World Women on Ecology, Feminism and Religion. (Maryknoll: Orbis Books, 1996)161-171.

3 Susan Rakoczy, In Her Name: Women Doing Theology (Pietermartizburg: Cluster Publications, 2006) 302.

4 Lilian Cheelo Siwila, "Tracing the Ecological Footprints of our Foremathers: Towards an African Feminist Approach to Women's Connectedness with Nature," Studia Historiae Ecclesiaticae 40, 2 (2014): 137.

5 Jamie Thompson, "Ecofeminism: The Path towards Healing the Earth," Dialogue \& Nexus Vol. 4, Article 8.(2017): 1. 
earth as well as other oppressed groups." Ifechelobi and Asika articulate the principles of eco-feminism as follows:

Eco-feminism is based on the theory that the subjugation of women and the oppression of nature are linked together. Eco-feminism is linked to the study of the internal and intricate relationship between women and ecology. The theory projects that the subjugation of women and the oppression of nature are linked together. Discrimination and oppression due to power, class, gender and race are directly related to the exploitation of the environment. In patriarchal societies, women and nature are ordinarily seen as fertile and capable of providing life, care and shelter. ${ }^{6}$

Our article adopts the African eco-feminist theoretical framework because the tenets of ecofeminism concur with the reality of the situation on the ground in Chimanimani and Chipinge where women and children bore the brunt of burden in the aftermath of Cyclone Idai. For instance, the official statistics in Zimbabwe reveal that more than $80 \%$ of the people who either lost their lives or were injured during the Cyclone Idai catastrophe were women and children. Additionally, women were responsible for most of the care giving and humanitarian work in the wake of the Cyclone Idai disaster. This illustrates the fact that the ecological crisis has a far-reaching impact on those who are pushed to the periphery of society within patriarchal communities. Hence, our adoption of African ecofeminism concurs with Jamie Thompson's ${ }^{7}$ assertion that "the oppression of women and the exploitation of the earth is further connected because, historically, women and nature have been tied together." In adopting African feminism as our

6 Jane Nkechi Ifechelobi and Ikechukwu Emmanuel Asika, "Women and Ecology: An EcoFeminist Reading of Chinua Achebe's Things Fall Apart," International Journal of English Literature and Social Sciences Vol. 2, no.4, (July - Aug 2017):33.

7 Thompson, "Ecofeminism: The Path towards," 2. 
theoretical lens, we also concur with Munamato Chemhuru ${ }^{8}$ who posits the argument that:

Ecofeminist philosophical thinking in general is a broader feminist view concerned with understanding environmental justice by looking at social structure, while the African ecofeminist perspective is part of this broader perspective, but being particularised in the African context.

The framing of our article therefore resonates with the views raised by Chemhuru because we seek to foreground how the Cyclone Idai disaster can be understood from the perspective of ecofeminism within the African context, with particular reference to the experiences of women and children in Chimanimani and Chipinge districts. The findings in our field research reiterate that humanity's negligence or failure to care for the earth has major consequences on their well-being: The survivors participating in the study upheld that humanity's sustenance has a strong spiritual link with how humans interact with Mother Earth. Below, we discuss how the study participants interpreted the occurrence of Cyclone Idai from a religious perspective.

\section{Religious interpretations of Cyclone Idai}

Like any other indigenous African community, the survivors of Cyclone Idai in Chimanimani and Chipinge districts reflect on the fateful natural disaster with spiritual lenses. This is because the indigenous African communities perceive the cosmos as a spiritual entity. As such, nothing happens by sheer chance; instead, any incident, whether good or bad, is interpreted from a religious perspective. Speaking of symbols, rituals and community in African religions, Ray aptly captures this worldview when he observes that "the spiritual world of the Africans is densely populated with spiritual beings,

8 Munamato Chemhuru, "Interpreting Ecofeminist Environmentalism in African Communitarian Philosophy and Ubuntu: An Alternative to Anthropocentrism," Philosophical Papers 48, no.2 (September 2018): 11 10.1080/05568641.2018.1450643. 
spirits and the living-dead." 9 The African perspective regarding this spiritual worldview is that every effort must be made by the living to maintain peace and harmony with the spiritual entity. As noted by Dahlin ${ }^{10}$ and Shoko ${ }^{11}$, if aggrieved in any way, the ancestral spirits have the potential to cause pandemonium among their descendants, consequently exposing them to all sorts of misfortunes [kuvhurira mhepo], such as, being struck by complex natural disasters, allowing negative spirits to attack the descendants. and in some instances, causing mysterious loss of wealth or well-being among descendants.

Writing specifically about the Karanga people, a sub-group of the Shona in Zimbabwe, Aschwanden ${ }^{12}$ notes that the Karanga believe that the midzimu spirits are essentially positive, but if they are provoked, they can either turn against humans and cause misfortune or they can withdraw their protection and allow harm to befall them. This deeply African spiritual worldview is also articulated by J.S. Mbiti as follows:

Any misfortune must have a traceable cause, even if someone comes down with malaria after having been bitten by mosquitos, the African people would still want to investigate why that particular person was bitten by mosquitos and not the others with the intention of establishing who or what is behind the unleashing of the mosquitos. ${ }^{13}$

In the same light, the people in Chimanimani district use their indigenous knowledge systems and their understanding of the spiritual worldview to

9 Benjamin Caleb Ray, African Religions: Symbol, Ritual and Community (Prentice Hall: London, 1976), 78.

10 Olov Dahlin, Zvinorwadza: Being a Patient in the Religious and Medical Plurality of the Mberengwa District, Zimbabwe (Universitetstryckeriet: Uppsala, 2000), 120.

11 Tabona Shoko, Karanga Indigenous Religion in Zimbabwe: Health and Well-Being (Ashgate: Ashgate Publishing Limited, 2007), 87.

12 Herbert Aschwanden, Symbols of Death (Mambo Press: Gweru, 1987), 98.

13 John.Samuel Mbiti, African Religions and Philosophy (Oxford: Heinemann Educational Publishers, 1990), 65. 
interpret the occurrence of the drenching rains, mudslides, drowning, death and devastation in the wake of the Cyclone Idai catastrophe.

In congruence with African feminism which perceives the earth from a feminine perspective as is denoted by the use of the term Mother Earth, the survivors of Cyclone Idai also interpreted the catastrophe as an illustration of their maternal spirits having deserted them. This was revealed in their use of the proverb, midzimu yamai yakadambura mbereko (our maternal spirits withdrew their protection from us and left us susceptible to this ecological carnage). This is informed by the entrenched Shona people's belief that one's maternal spirits are the most protective, hence, if they become incensed and remove their protection from an individual, he/she becomes predisposed to all forms of vicious attacks.

\section{"Demonstrating the power of God the father": Summarizing Christian interpretations}

Upon interacting with various survivors of Cyclone Idai during field research, it became apparent that both adherents of ATR and Christianity tend to use indigenous interpretations in trying to make sense of this disastrous phenomenon. Some Christians interpreted the cyclone as a sign of God's rage against the sinful and permissive behaviour of the local people. Their vantage point for interpreting the cyclone as a sign of God's wrath was the argument that even though almost every building was swept off by the raging waters, mudslides and rolling, sliding boulders, both in Ngangu settlement in Chimanimani and in Ndakopa community in Chipinge, the church buildings in both places survived the calamity and became places of sanctuary for the surviving communities who lost their homes to the cyclone. A male survivor who was volunteering his time to coordinate distribution of donations at the Roman Catholic Church in Ngangu where the bulk of the survivors sought sanctuary put it across as follows:

On the fateful night, without having been instructed by anyone, people ran for dear life from various sectors of Ngangu settlement and converged at this church building for sanctuary. The first group to 
arrive here had to force open the locked doors of the church building in order to gain entry. No sooner had they entered did others start arriving. Some brought their injured relatives and as the night progressed, slowly, other members of the community began to bring the corpses of their loved ones into the church building. Since it was extremely cold and most of the injured were shivering from the cold, we resolved to light a fire inside the church and had no recourse than to dismantle the wooden benches in the church to use them as firewood. The other church building that was spared the devastation here in Ngangu belongs to the Methodist Church. In the same manner that those who live in close proximity to this (Roman Catholic Church) building all thronged here, those residing near the Methodist Church also rushed to seek refuge there. ${ }^{14}$

The general conception among the people who survived the cyclone in Chimanimani is that the Lord God mysteriously saved the church buildings to demonstrate God's glory, as well as to provide sanctuary for the survivors. Another middle-aged woman residing in Chimanimani village who described the ordeal of the cyclone had the following to share:

The [Zimbabwe Assemblies of God Africa] ZAOGA church in Ngangu miraculously survived the trail of destruction. Some survivors sought refuge inside the church and the pastor's house which is the only house that survived the devastation in that area. The huge boulders that swept off other houses and buildings within the vicinity of that area astoundingly formed a barricade around the ZAOGA church and the Pastors' house such that even the mudslides which destroyed most of the infrastructure in Ngangu did not find a pathway into the ZAOGA church stand. In Ndakopa where whole communities were swept off by the ferocious flood waters, another ZAOGA church building survived the onslaught and all those who sought refuge inside the church survived the calamity. We believe that God is speaking to

14 Personal Interview, Ngangu Residential area in Chimananini, April 28, 2019. 
us and although we are aggrieved by the losses of so many lives and belongings, we believe that God has plans for the greater good in our lives. ${ }^{15}$

The Jehovah's Witnesses' Kingdom Hall also survived unscathed. One of the new converts to the Jehovah's Witnesses said that she was touched by the fact that their building remained intact in the face of the merciless pounding by the cyclone.

I was attracted to the Jehovah Witness church because of their church building that remained intact in Chimanimani after Cyclone Idai devastation. To me, it showed that God was indicating something to this generation in that church. ${ }^{16}$

It must be observed that in rural Zimbabwe, in general, church buildings tend to be built on high ground. There are both theological reasons for this development (to be visible/imposing/quest for permanency) and practical reasons (safety). While scientists would concentrate on the physical explanation, Christians view the proceedings through the eyes of faith. For them, it is inconceivable that church buildings would be spared "by a random act of nature, or by dint of sheer physical location." They utilize a theological frame to explain how church structures became sanctuaries during the devastation.

Other Christian explanations adopted eschatological and moralistic themes. Thus, according to them, just as God came down on an apostate generation during the time of Noah (Genesis 6:9-9:17), so did God decide to prefigure the sure end of time through Cyclone Idai. Some study participants maintained that there was simply too much corruption, debauchery, wretchedness and mocking of God for God's wrath not to be provoked. They felt that while the death of the people of Chimanimani and the loss of

Personal Interview, Chimananini Village, 27 April, 2019.

Jena Nunurai, "Thousands of Witnesses Besiege Chinhoyi," NewsDay, July 31, 2019. 
property and general devastation was unfortunate, it served as a reminder that the end of the world is very near indeed. As Nyahuma has demonstrated, there is a strand of Zimbabwean Christianity that insists that the world's "extreme loss of morals" portends the end of the world. ${ }^{17}$

Study participants who insisted that the world/Zimbabwe had become "too sinful" did not in any way suggest that the people of Chimanimani in general, or the victims in particular, had more sins than those in other places that did not experience the disaster. They maintained that God's sovereignty cannot be questioned. Therefore, God saw it fit to demonstrate God's power through Cyclone Idai. The message was clear: people had to leave their wicked ways and turn to God while there was still a window of opportunity. Although there are serious ethical challenges associated with this explanation, it had some enthusiastic supporters.

Wearing African eco-feminist lenses, one cannot stop questioning why and how, if God is all-loving and all-caring, there were so many innocent lives lost during the Cyclone Idai carnage. Why did God not just punish the sinful people and spare the rest of the innocent folks? Cognizant of the fact that $80 \%$ of the people who suffered the most during the disaster were women and children, the Cyclone Idai misfortune affirms the eco-feminist contention that the ecological crisis has a gendered dimension.

\section{"Annoyed Ancestors": An overview of indigenous interpretations}

Besides these interpretations of Cyclone Idai from members of the Christian community in Chimanimani and Chipinge districts, there were several African traditional interpretations tendered by the residents of Chimanimani regarding the possible causes of the disaster. An elderly female survivor

17 Blessing Nyahuma, "The Whore of Babylon: Gender Metaphors in the Revelation of John and the Use of Apocalyptic Language in Response to Changing Gender Roles in Zimbabwe," in The Bible and Gender Troubles in Africa, eds. J. Kügler, R. Gabaitse and J. Stiebert (Bamberg: University of Bamberg Press, 2019), 89. 
residing in Ngangu shared her conceptualization of the original cause of the cyclone as follows:

We believe that the desecration of the sacred clay pots which resided in a sacred cave on top of Ngangu Mountain perpetrated by some overzealous Christians is the reason behind the ancestral wrath resulting in the unleashing of this calamity. Since time immemorial, the sacred cave has always been revered as the abode of the highly respected ancestral spirits of our land [mudzimu mukuru]. It is an extremely beautiful natural cave which attracts pilgrims from the adherents of both Christianity and African traditional religion. Traditional rituals used to be performed inside the cave, especially rainmaking ceremonies and thanksgiving for good harvests. With time, some Christian groups have also designated the cave as their favourite spot for conducting night vigils whilst praying, fasting and meditating. Inside the cave, there are artistic rock paintings believed to have been inscribed by the San during the pre-colonial period. Several unusual objects as well as sacred clay pots filled with rapoko are found inside the cave. Unfortunately, it is said that some Apostolic and Pentecostal Christian groups decided that the sacred clay pots were objects belonging to "heathen groups upholding evil traditions" and they decided to destroy the clay pots. Such an act is believed to have infuriated the ancestral spirits and raised their ire; hence, the ancestors expressed their indignation by causing the heavy rains, mudslides and the rolling of the stones from the mountain. ${ }^{18}$

Clearly, the destruction of the sacred clay pots did not sit well with those who still uphold the traditional African worldview. The general consensus among the residents of Chimanimani is that it needs no genius to fathom that there is a spiritual reason behind the fact that Ngangu Mountain, which used to be their source of water, well-being and sustenance, suddenly became the

18 Personal Interview, Ngangu Residential area in Chimananini, April 28, 2019 
source of devastation, death and destruction. Their cherished source of enrichment, safety and security precipitously became their enemy. Such an abrupt turn of events could only be explained using their indigenous knowledge systems. They believe that the ancestral spirits, whose main abode is Ngangu Mountain, either abandoned them or withheld their protection and exposed the whole community to this tragedy.

It is critical to note that there is a silent war relating to sacred sites that is raging across Zimbabwe. Traditionalists are locked in a spiritual battle against members of African Independent Churches (especially the whitegarment/Apostolic type) and newer Pentecostal churches when it comes to sacred places. For example, the Great Zimbabwe Monument, a UNESCO World Heritage Cultural Site, attracts different religious groups who lay claim to it. ${ }^{19}$ Similarly, Musoni describes contestation for holy places in Zimbabwe's religious landscape. ${ }^{20}$ The emerging Pentecostal churches have also argued that God has given them mountains that were previously associated with traditional religion. In one sense, this has contributed towards a positive environmental ethic. However, it has also generated animosity and pollution. ${ }^{21}$

An elderly male cyclone survivor who described himself as a renowned traditional herbalist and a resident of Ngangu, interpreted the occurrence of Cyclone Idai as follows:

19 Munyaradzi Mawere, Munyaradzi Elton, Sagiya and Tapiwa Raymond, Mubaya, "Convergence of Diverse Religions at Zimbabwe Heritage Sites: The Case of Great Zimbabwe National Monument," International Research Journal of Arts and Social Sciences 1, no.2 (2012): 25.

20 Philip Musoni. "Contestation of 'the Holy Places in the Zimbabwean Religious Landscape': A Study of the Johane Masowe Chishanu yeNyenyedzi Church's Sacred Places," HTS Teologiese Studies/ Theological Studies 72 no.1 (2016): 44, http://dx.doi. org/10.4102/hts.v72i1.3269.

21 Golo Ben-Willie Kwaku, "Creation and Salvation in African Neo-Pentecostalist Theology," in Creation and Salvation: A Companion on Recent Theological Movements, Vol. 2, ed. Ernst M. Conradie (Zurich: LIT, 2012): 66. 
Before the outbreak of Cyclone Idai, our interaction with the mountain had been one of interdependence. Growing up, our elders engraved in our hearts that Ngangu Mountain has sacred significance. Our indigenous teachings passed on from one generation to the other inscribed in us the understanding that the mountain is a special gift from above. We enjoyed a cordial relationship with our mountain and always looked up to it as our source of livelihood and abundant living. When my grandfather started grooming me as a herbalist, we would climb the mountain to collect several medicinal herbs and I have maintained the tradition of collecting herbs from the mountain to treat my patients even in my old age. Ngangu Mountain has always been our continual source of clean water for domestic use and irrigation. We have always revered the mountain as a place of spiritual significance as well as our provider for water, food and medicinal herbs. Unfortunately, the coming in of vatogwa/vauyi [outsiders] from other parts of the country and from different parts of the world to reside in Chimanimani brought in conflicting religious and cultural beliefs and practices which threatened the prevailing harmonious co-existence with our mountain. All hell broke loose after the unfortunate incident whereby a white farm owner whose farm was adjacent to Ngangu Mountain shot and killed several mhondoro (lions believed to be the harbingers of the ancestral spirits). The mhondoro permanently resided on the mountain but would sometimes roam around the neighbourhood and prey on domestic animals. The white farmer was concerned that the mhondoro were depleting his livestock and so he decided to shoot the mhondoro dead. As much as his farm workers who were locals tried to dissuade him from such detrimental action, he went ahead and shot the mhondoro. Shooting the mhondoro was a direct affront against the ancestral realm and we all knew that this would not end well. Clearly, the Cyclone Idai disaster is a result of the ancestors' outrage against such a slur. When ancestral spirits are aggrieved, they express their grievances through withholding 
their protection of the community from harm, consequently exposing them to all manner of misfortunes. ${ }^{22}$

From the information presented in the above excerpt, it is apparent that the indigenous interpretations of the Cyclone Idai catastrophe are anchored on the community's relationship with the ancestral spirits of the land. They believe that whenever they maintain peaceful and harmonious relations with the spirit world, they will be guaranteed safety, protection and abundance of life. Conversely, whenever relations with the spirit world have been negatively interrupted, there will be far reaching repercussions just as what transpired in the Cyclone Idai calamity. What is most unfortunate is the fact that whenever the spirit world registers its rage, it is not usually directed at the individual perpetrator who caused them to be furious; often times even the innocent ones become major causalities. If we are to embrace these indigenous explanations of what ignited Cyclone Idai, it would lead to the simple conclusion that most of the people who lost their lives, their loved ones and their belongings in the wake of the cyclone were merely caught in a vicious cycle of events beyond their control. They were caught in the crossfire without being directly responsible for their misfortune. Bujo poignantly illustrates this point:

Africans operate on the premise that "Everybody's behaviour and ethical action have consequences for the whole community: the good contributes to the increase of life, while evil destroys or at least reduces life." 23

Whenever death and destruction strikes, African indigenous communities immediately turn to their indigenous knowledge systems for explanation. As such, the Chimanimani communities also proffer their indigenous understandings of what might have caused the untold misery and devastation wrought by Cyclone Idai. The other explanation tendered by the

22 Personal Interview, Ngangu Residential area in Chimananini, April 28, 2019.

23 Benjamin Caleb Bujo, The Ethical Dimension of Community: The African Model and Dialogue between North and South (Nairobi: Paulines Publications Africa, 1998), 189. 
residents of Chimanimani emerges in the above excerpt. Everyone practicing farming or mining within that community brewed traditional beer annually and offered sacrifices as a sign of thanksgiving and respect for the protection and provision of abundant harvests by the spirits. The white farm owner incited ancestral indignation by adamantly refusing to propitiate them through such practices or offerings. Consequently, the spiritual realm registered its dissatisfaction by sending the mhondoro to devour his livestock as a warning. Instead of conceding and doing the needful, the farm owner retaliated by shooting and killing the mhondoro which further infuriated the spirit world forcing them to strike back harshly in the form of the calamitous cyclone.

The shooting and killing of the mhondoro by a mutorwa/muvuyi [foreign national] is perceived as literally the last straw that broke the camel's back. Relations between the spiritual realm and the Chimanimani communities are believed to have been strained already due to the desecration and destruction of the sacred cave and the clay pots on Ngangu Mountain as described in the earlier section. Consequently, the mhondoro shooting incident is regarded as the final blow unleashing the ancestral vengeance making the Cyclone Idai tragedy inevitable. Such an indigenous interpretation resonates with the view put forward by Chirongoma and Manda:

In the African world-view, life should be lived to the fullest and in appreciation of others. There is a strong impulse to secure life through the practice of good habits. Illness or any other type of misfortune is therefore interpreted as the work of evil especially if customary practices are being upheld. ${ }^{24}$

24 Sophia Chirongoma and Domoka Lucinda Manda, "Ubuntu and Women's Health Agency in Contemporary South Africa" in From Our Side: Emerging Perspectives on Development and Ethics, eds. Steve de Gruchy, Sytse Strijbos and Nico Koopman (Amsterdam: Rozenberg Publishers, 2008), 196. 
Official statistics on the Cyclone Idai carnage reveal that of the majority $(80 \%)$ who died, were injured or reported missing, most who are feared to have been swept into the ocean were women and children. Whilst children are celebrated as the community's future, women are also valued as the bearers and nurturers of life. Hence, a disaster of such magnitude where women and children abruptly and needlessly lost their lives caused community's anguish and led to uncertainty about the future. Writing specifically about the Karanga-Shona in Zimbabwe, Chitando explicates this indigenous perspective on life as follows:

African beliefs and practices are a celebration of life. Life is good and must be enjoyed to the full. Life must be enhanced and celebrated. Traditional Africans are stubbornly Earthbound, that is, they are not preoccupied with the idea of a world to come...The dominant belief is that one should live to a ripe old age...Traditional African beliefs and practices promote a pro-life agenda. ${ }^{25}$

Hence the traditional African reveres life; there is a preoccupation with longevity and abundance in the physical life. Anything that threatens or diminishes life is to be resisted and avoided. As such every effort is made to ensure that a fortuitous disaster such as Cyclone Idai is never repeated in the future. The intertwined connection between ecological disasters and the suffering of African indigenous women is also highlighted in various writings of African eco-feminist scholars who argue that the suffering of the earth perpetuates women's suffering since they are the ones in charge of domestic chores such as preparing food, fetching water and firewood. Hence, the scarcity of these resources adds an extra burden to their daily chores. ${ }^{26}$ The

25 Ezra Chitando, Living in Hope: African Churches and HIVIAIDS 2. (Geneva: WCC Publications, 2007), 47-48.

26 See the following works by Sophie Chirongoma "Women Curbing Ecological Degradation: Hope for Transformed Lives Inspired through Inter-faith dialogue between Shona Religion and the Christian Faith in Masvingo, Zimbabwe," in Voices From the Third World: InterFaith Dialogue Listening to African Voices, ed. K.C. Abraham, (India: Ecumenical Association of Third World Theologians, 2005), 39-60 Volume XXV111 No.2; "Motherhood and Ecological Conservation of Mother-Earth" in Women in God's Image: Images of God 
African indigenous explanations proffered by the study participants, particularly the vulnerability of women and girls to the Cyclone Idai carnage, also echo the views raised by Siwila, writing in the Zambian context who said the following:

In view of the current ecological challenges that are more pronounced for women than men, there is a need to embrace new ways of engaging in ecological debates. One way [to do this] is to examine how society has responded to indigenous knowledge derived from the peripheral of our societies...To what extent can these teachings contribute to discussions on the value of ecological indigenous knowledge to the sustainability of nature, and how can such discussions broaden the dialogue on the field of African ecofeminism, especially in the field of African Traditional Religions ${ }^{27}$

Hence, our explorations of the study participants' views concur with the voices of African eco-feminists such as Siwila cited above, who propound for a deeper understanding of African indigenous values in an endeavour to make sense of the current ecological catastrophe. We also cohere with Siwila's proposition for Africans to acknowledge the efficacy of indigenous knowledge to effectively address the ecological crisis in our respective African contexts. She argues thus:

[There is] a need to appreciate the value of indigenous knowledge, especially in today's society where theologians are continuously challenged to seek other ways of practising theology... If religion is

the Mother, ed. Karen Buckenham (City Printing Works Private Ltd: Pietermaritzburg, 2005), 8-12; "Karanga-Shona Rural Women's Agency in Dressing Mother Earth: A Contribution Towards an Indigenous Eeco-feminist Theology" in Journal of Theology for Southern Africa: Essays in Honour of Steve de Gruchy Vol 142, (March, 2012):120-144; "Eco-Feminism and Gender Justice: The Missing Link in Laudatio Si" in Journal of Theology for Southern Africa (ed) Andrew Warmback and Sue Rackozy, Volume 157, No 1. (2017):135-171.

27 Siwila, "Tracing the Ecological Footprints of our Foremathers,"141-142. 
to meet the demands of its adherents, especially those at the peripheral of society, there is a need to embrace their value systems. Indigenous knowledge in this case is one value system that has been challenged by modernity and colonialism to the extent that some religions have threatened to do away with some of the practices that carry along valuable indigenous knowledge. ${ }^{28}$

Some study participants also underscored the value of the area that was devastated by the cyclone, namely, Chipinge. They reiterated that this area was the seat of indigenous spirituality. They said that Chipinge is associated with kupinga (to lay the foundation of/to anchor/to establish) in Zimbabwe. Thus, it is not an ordinary place. To borrow the formulation by Eliade, Chipinge is the country's very own axis mundi or, 'center of the world. ${ }^{29}$ In this scheme, events in Chipinge are not to be interpreted in isolation: they carry a message to the whole country. Therefore, political leaders need to take corrective action and communicate with the ancestors through the traditional leaders in order to correct the wrongs done by this generation.

The indiscriminate punishment which is believed to have been meted out by the aggrieved ancestors also raises major ethical concerns. The overarching question that one is left asking is, "why did the aggrieved ancestors not unleash their wrath on the offenders only, rather than indiscriminately punishing all and sundry?" In the backdrop of this question, the next section focuses on navigating indigenous solutions to unpredictable weather patterns.

\section{Indigenous solutions to unpredictable weather patterns}

As noted above, the indigenous understanding within the Chimanimani and Chipinge communities is that there is co-existence between the living folk and the spiritual realm that encompasses all facets of the environment. Safety, security and abundant living is dependent on how the living folk 
interact with the spirit world. ${ }^{30}$ Any breaking of environmental taboos or deliberate negligence of traditional norms and values disrupts the peaceful co-existence causing the ancestral spirits to withdraw their protection from the living folks consequently exposing them to misfortunes, especially natural calamities such as the tragedy suffered in the wake of Cyclone Idai. The general consensus among the indigenous communities is that the living should strive to maintain a balance between themselves, the ancestors and the environment. ${ }^{31}$ The preservation of water sources such as the waterways in Ngangu and Ndakopa is regarded as a sacred responsibility. Failure to preserve these sacred sites results in disaster as seen in the devastation experienced during the cyclone. If these sites had been perpetually persevered as had been done in the past, the loss of lives and infrastructure could have been averted despite the mudslides and the torrential rains.

Although there were various religious explanations proffered in trying to make sense of this catastrophe, some survivors also explained that human error contributed immensely towards the loss of lives. First, the two sections of Chimanimani that suffered heavy losses of life i.e., Ngangu and Coppa had been designated as human settlements by the district council while knowing fully well that these geographical locations were waterways. As such, when the heavy rains soaked the soil, the water escaped via these weak points and in the process, all the homes and the residents were swept away by the raging waters. Second, if the Department of Civil Protection (DCP) had promptly evacuated the residents to safety, they could have saved many lives. The survivors shared harrowing stories of how they were not alerted of the looming disaster from the mudslides that began pouring into their homes at night. As they ran for dear life, some of their family members got stuck in the mud and could not make it to safety. Some also

30 Taringa Nisbert Taisekwa, Towards an African-Christian Environmental Ethic (Bamberg: University of Bamberg Press, 2014), 49.

31 Tabona Shoko, Karanga Indigenous Religion in Zimbabwe: Health and Well-Being (Ashgate: Ashgate Publishing Limited, 2007), 79. 
explained how their neighbors were fast asleep when disaster struck and hence, whole families were swept off by the heavy rains and the mudslides and they remain buried underground by a heap of stones where their homes once stood.

Many displaced individuals sought shelter in overcrowded spaces and the lingering trauma of losing all that was dear to them was immeasurable. What was even more heart wrenching was the manner in which most of the survivors living in the temporary shelters were masking their trauma and hopelessness by drowning themselves in drugs and alcohol. This was a common feature among all age groups - male and female - in all the temporary shelters. The ones who suffered the most during this climate related catastrophe were women and children. For instance, some women and girls related harrowing stories of how they became susceptible to various forms of dehumanization and exploitation during their stay in the temporary shelters. A young woman shared the following:

Losing our homes and our source of livelihood has heavily impacted on our humanity and dignity as women. Some of the devious male humanitarian workers and some unscrupulous government officials take advantage of our vulnerability and solicit for sexual favors before allocating us bare necessities such as tents, food, clothing and sanitary ware. Also, due to prolonged periods out of school, some of the idle girls are engaging in pre-marital sex or entering into early marriages in order to escape from the poverty and uncertainty confronting them. ${ }^{32}$

Third, some of the survivors died due to the prolonged delay in receiving external help. Survivors explained how they helplessly watched their loved ones writhing in pain after having sustained severe injuries from getting stuck in the mud or being hurt by the boulders falling from the mountain and other stones emerging from the ground due to the heavy rains and mudslides.

32 Personal Interview, Ngangu Residential area in Chimananini, April 28, 2019. 
They emotionally related how they remained cut off from the rest of the country for three days, with no food supplies, no electric power amidst the chilling weather with no life-saving medical help. Since their roads had been destroyed and the weather was foggy, they could not be reached either by road or by air. Some related how they sought shelter in church buildings located on higher ground where they spent days huddled together with the corpses of their loved ones as well as gravely ill family members some of whom gave up the fight after failing to receive the much-needed help in time.

Clearly, poor planning in terms of risk and disaster management as well as lack of due diligence in allocating residential stands precipitated the loss of lives that could have been averted under normal circumstances. Now what remains is just but a heap of stones covering the place they used to call home, stones burying memories of a once-upon-a-time integrated, happy, and thriving community. The pain, suffering, loss and trauma endured by the survivors of Cyclone Idai should raise a clarion call to those in positions of authority to exercise more vigilance, due diligence, and foresight to avail adequate resources to facilitate the evacuation of vulnerable communities to safety. On the part of the affected community, the important lesson that will hopefully be derived from this deeply unfortunate calamity is to take heed of warning signs in the event of future natural disasters and seek sanctuary timeously. No amount of compensation will ever heal the wounds of trauma suffered by the Chimanimani and Chipinge community as a result of the effects of Cyclone Idai. Granted, we cannot turn back the hands of time. However, we could take a leaf from how other countries and continents are successfully implementing their risk and disaster management initiatives and ensure that we also do the needful.

It is becoming crystal clear that climate change's most devastating effects will intensify among the world's poorest and most vulnerable communities. While those who have contributed the most to climate change, such as the rich communities of the Global North, experience the least impact, communities in the Global South will have to intensify efforts for survival. Therefore, it is important for activists at different levels to remind, particularly 
religious leaders, of their prophetic role. They must invest in standing with the communities in places such as Chimanimani and Chipinge, long after the television cameras have left ... in search of the next disaster elsewhere! As Chitando has argued, it is vital for African religious leaders to stand in solidarity with vulnerable communities that are facing the effects of climate change. ${ }^{33}$ From an African eco-feminist perspective, it is also important to interrogate the fact that women in the Global South are the ones who are bearing the brunt of the global ecological crisis. Such a status quo should spur African governments and African religious leaders to make concerted efforts towards putting measures in place to reduce the carbon footprint whilst paying particular attention to the plight of women and girls whose quality of life has been further diminished by the perpetually increasing ecological disasters. This view is aptly put across by Munamato Chemuru ${ }^{34}$ who posits that:

... the African ecofeminist philosophical view, which challenges all forms of domination and oppression, implies that if the origin of human social and political problems is understood and addressed, then it would also be easier to comprehend and address environmental problems as well.

\section{Conclusion}

Drawing insights from African ecofeminism, our article has attempted to find responses to the overarching question raised in the title of this article, "What did we do to our mountain?" This question denotes the indigenous people's perplexity as they grapple with coming to terms with the calamity in their midst. As explicated above, Ngangu Mountain which once represented a place for enrichment, sustenance, and was an oasis for abundant living, unexpectedly turned into a poisoned chalice and became an agent of death and destruction. Reminiscent of Mother Earth which is usually connected

33 Ezra Chitando, "Praying for Courage: African Religious Leaders and Climate Change," The Ecumenical Review 69 no.3 (2017): 427-428.

34 Chemhuru, "Interpreting Ecofeminist Environmentalism in African," 10. 
with nurturance and preservation of all life forms, Ngangu Mountain which was looked upon by the local people as their oasis of livelihood and wellbeing suddenly turned into a weapon of mass destruction. As Chimanimani district is well known for its rainy weather and fertile soils, when the rains started earlier in the week before the disastrous loss of lives and infrastructure on the night of the March 15, 2019, the residents of Chimanimani never suspected that anything was amiss. The assumption was that it was the normal rainy season and hence they expected it would end well. Even though several survivors acknowledge that they heard warnings of a looming cyclone, none of them foresaw the death-dealing, heart wrenching and life-diminishing catastrophic events that were to unravel in their midst. Whilst acknowledging that some individuals broke taboos and traditional prohibitions in their interaction with Ngangu Mountain and the sacred phenomena inhabiting the mountain, the survivors cannot help but feel let down by their beloved mountain and their ancestral spirits. Even those who uphold the Christian beliefs and values are left asking, "Where was God when this tragedy hit us?" More importantly, they feel let down by the government of Zimbabwe and its leadership, particularly considering that they remained cut off from any form of help for more than three days. They felt desperately alone and whilst numbed in pain and disbelief, they had to proactively salvage the limited resources at their disposal to make arrangements for mass burials of their loved ones who died due to the cyclone. "Never again!" must another community be left to perish due to a preventable disaster, or at least one whose impact could have been minimized with greater levels of preparedness and more timely reactions.

\section{References}

Aschwanden, Herbert. Symbols of Death. Gweru: Mambo Press, 1987.

Bujo, Benezet. The Ethical Dimension of Community: The African Model and Dialogue between North and South. Nairobi: Paulines Publications Africa, 1998.

Chemhuru, Munamato. "Interpreting Ecofeminist Environmentalism in African Communitarian Philosophy and Ubuntu: An Alternative to 
Anthropocentrism," Philosophical Papers, 48, no. 2 (September 2018): 1-24. DOI: 10.1080/05568641.2018.1450643.

Chirongoma Sophie "Women Curbing Ecological Degradation: Hope for Transformed Lives Inspired through Inter-faith dialogue between Shona Religion and the Christian faith in Masvingo, Zimbabwe." In Voices from the Third World: Inter-Faith Dialogue Listening to African Voices, edited by K.C. Abraham, 39-60. India: Ecumenical Association of Third World Theologians, 2005. Volume XXV111 No.2

"Motherhood and Ecological Conservation of MotherEarth" Women in God's Image: Images of God the Mother Nos 10\&11 April \& September, edited by Karen Buckenham, 8-12. Pietermaritzburg: City Printing Works Private Ltd, 2005.

"Motherhood and Ecological Conservation of MotherEarth." In Women in God's Image: Images of God the Mother Nos 10\&11 April \& September, edited by Karen Buckenham 8-12. Pietermaritzburg: City Printing Works Private Ltd, 2005.

"Karanga-Shona rural women's agency in dressing mother earth: A contribution towards an indigenous eco-feminist theology." In Journal of Theology for Southern Africa: Essays in honour of Steve de Gruchy Vol 142, (March, 2012):120-144

"Eco-Feminism and Gender Justice: The Missing Link in Laudatio Si." In Journal of Theology for Southern Africa Volume 157, No 1. edited by Andrew Warmback and Sue Rackozy, (2017):135-171.

Chirongoma, Sophia and Manda Domoka, Lucinda. "Ubuntu and Women's Health Agency in Contemporary South Africa." In From Our Side: Emerging Perspectives on Development and Ethics, edited by Steve de Gruchy, Sytse Strijbos and Nico Koopman, 189-208. Amsterdam: Rozenberg Publishers, 2008.

Chitando, Ezra. Living in Hope: African Churches and HIVIAIDS 2. Geneva: WCC Publications, 2007.

"Praying for Courage: African Religious Leaders and Climate Change," The Ecumenical Review 69, no.3 (2017): 425-435. 
Dahlin, Olov. Zvinorwadza: Being a Patient in the Religious and Medical Plurality of the Mberengwa District, Zimbabwe Universitetstryckeriet: Uppsala, 2000.

Eliade, Mircea. Patterns in Comparative Religion. London: Sheed and Ward, 1958.

Golo, Ben-Willie Kwaku. "Creation and Salvation in African NeoPentecostalist Theology." In Creation and Salvation: A Companion on Recent Theological Movements. Vol. 2. Conradie, edited by Ernst M. 62105. Zurich: LIT, 2012.

Ifechelobi, Jane Nkechi and Asika, Ikechukwu Emmanuel. "Women and Ecology: An Eco-Feminist Reading of Chinua Achebe's Things Fall Apart," International Journal of English Literature and Social Sciences 2, no. 4 (July - Aug, 2017): 33-40.

Jena, Nunurai. "Thousands of Witnesses besiege Chinhoyi," NewsDay, July 31, 2019.

Mawere, Munyaradzi, Munyaradzi Elton, Sagiya and Tapiwa R. Mubaya. "Convergence of Diverse Religions at Zimbabwe Heritage Sites: The Case of Great Zimbabwe National Monument," International Research Journal of Arts and Social Sciences 1, no. 2, (2012): 22-31.

Mbiti, John Samuel. African Religions and Philosophy. Oxford: Heinemann Educational Publishers, 1990.

Musoni, Philip. "Contestation of 'the Holy pPaces in the Zimbabwean Religious Landscape': A study of the Johane Masowe Chishanu yeNyenyedzi Church's Sacred Places," HTS Teologiese Studies/ Theological Studies 72, no.1 (2016) http://dx.doi. org/10.4102/hts.v72i1.3269.

Nyahuma, Blessing. "The Whore of Babylon: Gender Metaphors in the Revelation of John and the use of Apocalyptic Language in Response to Changing Gender Roles in Zimbabwe." In The Bible and Gender Troubles in Africa, edited by J. Kügler, R. Gabaitse and J. Stiebert, 315-338. Bamberg: University of Bamberg Press, 2019. 
Personal Interview, Chimananini Village, April 27, 2019.

Personal Interview, Ngangu Residential area in Chimananini, April 28, 2019

Rakoczy, Susan. In her name: Women Doing Theology. Pietermartizburg: Cluster Publications, 2006.

Ray, Benjamin Caleb. African Religions: Symbol, Ritual and Community. London: Prentice Hall, 1976.

Shoko, Tabona. Karanga Indigenous Religion in Zimbabwe: Health and Well-Being. Ashgate: Ashgate Publishing Limited, 2007.

Siwila, Lilian Cheelo. "Tracing the Ecological Footprints of our Foremathers: Towards an African Feminist Approach to Women's Cnnectedness with Nature," Studia Historiae Ecclesiaticae 40, no. 2 (2014): 131-147.

Taringa, Nisbert Taisekwa. Towards an African-Christian Environmental Ethic. Bamberg: University of Bamberg Press, 2014.

Thompson, Jamie. "Ecofeminism: The Path towards Healing the Earth." Dialogue \& Nexus 4 (Fall 2016-Spring 2017): 1-6

Zimbabwe National Statistics Agency 2012, "Census 2012 Provincial Report Manicaland." Accessed July 22, 2021. https://www.zimstat.co.zw/wpcontent/uploads/publications/Population/popu lation/Manicaland.pdf 